\title{
Sorbent Extraction of Some Metal Ions on a Gas Chromatographic Stationary Phase Prior to Their Flame Atomic Absorption Determinations
}

\author{
M. Soylak, ${ }^{*}$ S. Saracoglu, ${ }^{\dagger}$ and L. Elci ${ }^{\ddagger}$

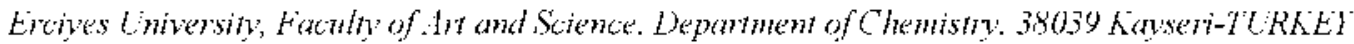

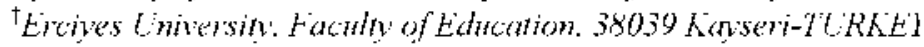

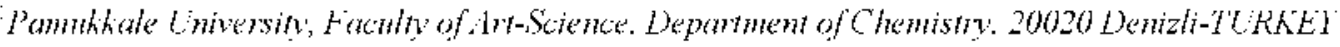 \\ Received Seprember 24, 2002
}

\begin{abstract}
An emichment/separation sy stem for atomic absomplion spectrometric deteminations of Cu(II), Fe(III), Ni(II) and $\mathrm{CO}(\mathrm{II})$ has been established. The procedure is hased on the adsorption of the analy tes as calmagite chelates

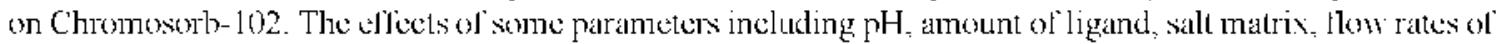
sample and eluent solutions were investigaled. Inder optimized eonditions, the relative standard deviation of the combined method of sample treatment, preconcentration and determination with $\Gamma$ AAS (N=5) is generally lower than 5\%. The limit ol detection $(3 \sigma)$ was helveen $6.0-112.9 \mu \mathrm{g} / \mathrm{h}$. The results vere uxed for protoneentration of analytes from some sodium and ammonium salt.
\end{abstract}

Key Words : l'race metals, Impurities, Chromosorb-102, Preconcentration, Calmagite

\section{Introduction}

The deterinination of trace impuritics in salt samples is important. because of the effects of the impuritics on some electrical. mechanical and chemical properties of the salt sample and the necessity of the ligh purity salt samples in certain arcas such as scmiconductors. nuclcar industry $\mathrm{clc}^{\text {. }}$ ? Atomic absorption spectrometry (AAS) is the onc of the important technique for the determination traces metals. To delermine trace melals in various samples by AAS. a separation and preconcentration tcchnique is frequently required. because of the low concentration of metals ions and the presence of interference. ${ }^{3}$

Marn melhods include membrane filtration. coprecipitation. solvent cxiraction. clond point extraction ctc. have becn developed for preconcentration of trace melals. ${ }^{3-6}$ The adsorption of 1race clements onto stationary phases has proved to be a valuable preconcentration technique because it provides very high concentration factors. compared the other techniques. and often permits an interference frec delemination. ${ }^{3-}$ The key to a successful separation of an analyte is the choice of the clicmical interaction between the analytc and column matcrial. Adsorption of complexed melals on sorbents. such as activatcd carbon. Amberlitc XAD resins. maplithalene. C-60. silicagel cte lave been widely applicd to the preconcentration of metals from various samples. ${ }^{8-12}$ Chromosorb resins (Chromosorb - 101. -102 . $-105 .-108 \mathrm{clc}$ ) are symthctic polymeric materials ${ }^{13.1 .4}$ and have becn uscd for gas chromatograply as stationary phases. because they liaxe good plysical and chemical propertics such as porosity. high sufface arca. durability and purity and are resistant in concentrated mineral acid. concentratcd bases and organic solvents for a long line.

"Comesponding author: phone and fax: +90 352 4374933, c-mail: soylak àcreyescodu.u
They have becn used for the preconcentration of traces heavy melal ions in the various samples. ${ }^{13-2]}$

Calmagite is widely uscd chelating agent that lias a larger formation constant with melal ions and is also used in preconcentration of metal ions. Ferreira et $a^{\text {2x }}$ have becn uscd calmagite as complexing agent for copper with the online sorption of the complexes on XAD-2. The determination of $\mathrm{Cu}$ by FAAS was performed after preconcentmation of calmagite complex on XAD-2, ${ }^{23}$ Calmagite was also used for the chriclument of Mo(VT) on activaled carbon. ${ }^{2+t}$ The preconcentration of calmagite metal complexes on cellulose nitrate membrane filter have becn performed by Soylak et al. ${ }^{25}$ The same reagent was used for the preconcentration of some metal ions from scawater samples on XAD- $180 .{ }^{26}$

In the present work. the analytical conditions for the quantitative recoveries of some metal ions as chelates with calmagite on Chromosorb-102 were investigated.

\section{Experimental Section}

Reagents and Solutions. Analytical reagent-grade chemicals were cmployed for the preparation of all solutions. Freshly prepared doubled distilled water. from a quart $\%$ sill. was uscd in all experiments. Stock melal ion solutions. $1000 \mathrm{mg} / \mathrm{L}$ (E. Merck) were diluted daily to oblaining reference and working solutions. Calmagite $\left(1.0 \times 10^{-} \mathrm{M}\right)$ was dissolyed in water and prepared daily. Chromosorb-102 (80-100 mesh) (Sigma) was washed successively with melhanol. water. I M $\mathrm{HNO}_{3}$ in acctone. water. $1 \mathrm{M} \mathrm{NaOH}$ and water.

Sodium phosphate buffer $(0.1 \mathrm{M})$ was prepared by adding an appropriatc amount of phosphoric acid (Mcrck) to sodium dityd drogen phosplate solution to result in a solution of $\mathrm{pH} 2$. Ammonium acetate buffers $(0.1 \mathrm{M})$ were prepared by adding an appropriate amount of acetic acid (Mcrck) to ammonium acclate solutions to result in solutions of $\mathrm{pH}$ 4-6 and ammonium cliloride buffer solutions $(0.1 \mathrm{M})$ were 
prepared by adding an appropriate amount of ammonia (Merck) to ammonium chloride solutions to result in solutions of pl] 8-10.

Instrument. The instrumental delection system used was a Perkin-Elmer Model $3110 \mathrm{AAS}$. The operaling parameters were those recommended by the manufacturer. $A$ Il measurements were carried out withoul background correction with air/acetylene flame. $\Lambda \mathrm{pl}]$ meter, $\mathrm{Nel}$ pl $[-900$ Model was employed for measuring $\mathrm{pl}$ I values in the aqueous phase. The samples were introduced to the nebulizer of $\Lambda \Lambda S$ by using micro injection method. ${ }^{27} 100 \mu \mathrm{L}$ of sample was injected to a mini home-made Teflon funnel with a Eppendorl Pipette. The Teflon funnel was connected to the nebulizer with capillar tubing. The peak height signals were recorded.

Column Preparation. $\wedge$ glass column with an inner diameler of $10 \mathrm{~mm}$ and a length of $100 \mathrm{~mm}$, equipped with porous firts, was filled up to a height of about $25 \mathrm{~mm}$ with a suspension of $500 \mathrm{mg}$ of resin in water. Prior to use, the resin was preconditioned with bufler solution. After each experiment, the column was rinsed with water and stored.

Test Procedure for Preconcentration. $A$ required volume of a $1.0 \times 10^{-2} \mathrm{M}$ solution of calmagite was added to $50 \mathrm{~mL}$ of solution containing $10 \mu \mathrm{g}$ of the each metal ion and brought to desired pl between 2 and 10 . The column was preconditioned with $10-15 \mathrm{~mL}$ of the water brought to the same pl $\mathrm{I}$ of working $\mathrm{pl}$. The sample solution was permitled to flow through the column at a flow rate of $5 \mathrm{~mL} / \mathrm{min}$. $\Lambda$ fter passing of this solution, the column was rinsed iwice with 10 $\mathrm{mL}$ of water. The retained metal-chelates were eluted with $10 \mathrm{~mL}$ portion of I $\mathrm{M} \mathrm{HNO}_{3}$ in acctone at a llow rate of 5 mLimin. The eluate was evaporated to near dryness. The residue was diluted to $2-5 \mathrm{~mL}$ with I $\mathrm{M}$ H INO.. The metal concentrations in the linal solution were determined by flame $\wedge \mathrm{AS}$.

Application to Real Samples. Five gram of salt sample was dissolved in $50 \mathrm{~mL}$ of distilled water. $2 \mathrm{~mL}$ of calmagite was added to this solution and the pJl of solution was adjusted to 8 with ammonium chloride buffer solution. The sample was passed through the column at a $5 \mathrm{~mL} / \mathrm{min}$, then, the adsorbed metal chelates to the column were eluted with $10 \mathrm{~mL}_{1} \mathrm{M} \mathrm{HINO}_{3}$ in acetone. The cluate was cvaporated to near dryness. It was diluted to $2 \mathrm{~mL}$ with $1 \mathrm{M} \mathrm{HINO}_{3}$. To detemine the analytes in the concentrated solutions, an aliquol $100 \mu \mathrm{L}$ of the solution was introduced to the nebulizer of $\mathrm{F} \Lambda \Lambda \mathrm{S}$ by microinjection method.

\section{Results and Discussion}

Effect of the pH on the Retentions. pIl is a very important factor for ellicient recoveries of analyte ions. The influence of $\mathrm{pH}$ on the solid phase extraction was studied in the range of $2-10$. The $p l$ ls of the each solution wete adjusted by the addition of relevant buffer solution given in the Experimental and were controlled by pll meter. The results are presented in Figure 1. The recovery depended on the $\mathrm{pH}$ I that was nearly constant in the $\mathrm{pI}$ l range of 6-10,4-10

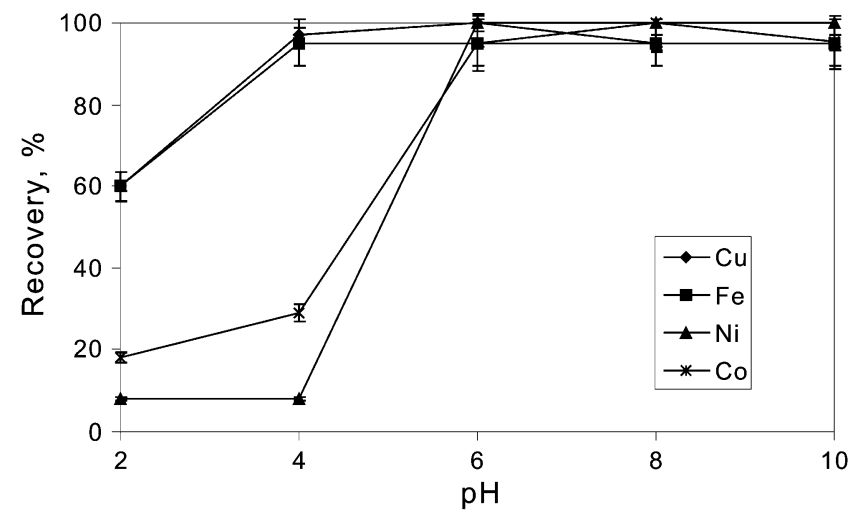

Figure 1, pll dependence of the recoveries of the metal ions (eluent: $10 \mathrm{ml}$. of I $\mathrm{M} \mathrm{IINO}_{3}$ in acetone. metal amounts: $10 \mathrm{Hg}$. $\mathrm{N}=3$ ).

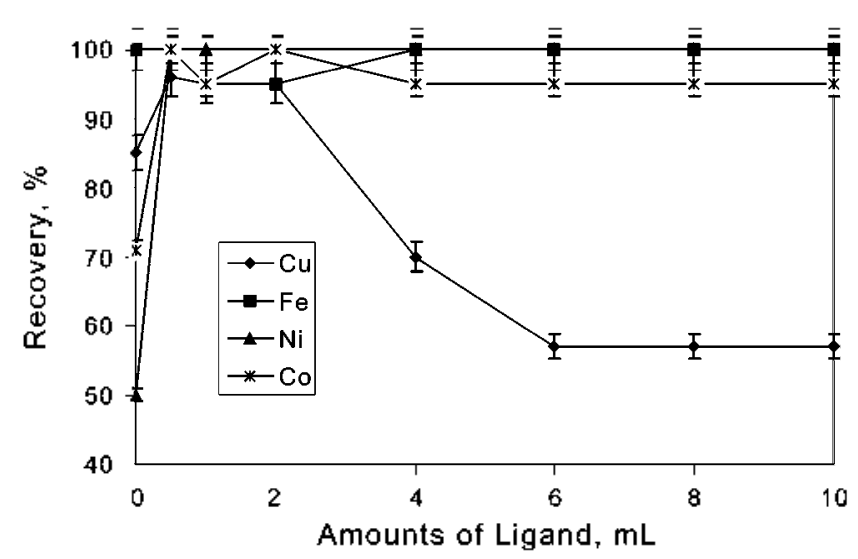

Figure 2. Changes on the recoveries of metal ions with calmagite amounts $(\mathrm{N}=3$. cluent: $10 \mathrm{~mL}$ of $1 \mathrm{MHNO}$; in acetone).

for $\mathrm{Ni}$ and $\mathrm{Co}, \mathrm{Cu}$ and $\mathrm{Fe}$ respectively. $\mathrm{pI} 8$ was selected as working pll. The volume of the buffer solution had no ellicient eflects on the recoveries.

Influences of the Amounts of Calmagite. The inlluences of the amounts of calmagite on the recoveries were also examined. The results are given in Figure 2. The recoveries, $\geq 95 \%$, are quantitative for each of $\mathrm{Fe}, \mathrm{Ni}$ and $\mathrm{Co}$ in the examinated range, for $\mathrm{Cu}$ in the range $0.5-2 \mathrm{~mL}$ calmagite. The recoveries obtained from the sample solution withoul calmagite were not quantitative except for $F \mathrm{c}$. $A l 1$ further studies $2 \mathrm{~mL}$ of calmagite was used as ligand.

The Effect of Eluent Type. The elfects of eluents on the recoveries of analytes from Chromosorb-102 were also investigated. Quantitative recoveries for all analytes were obtained with $10 \mathrm{~mL}$ of $1 \mathrm{M} \mathrm{IINO}_{3}$ in acetone. The recovery of nickel was quantitative with all of investigated cluent. While with I $\mathrm{M} \mathrm{IINO}_{5}, \mathrm{Cu}, \mathrm{Fe}$ and $\mathrm{Ni}$ were quantitatively recovered, with acetone, only $\mathrm{Ni}$ and $\mathrm{Co}$ were quantitatively recovered. Also, selective eluation of metal ions were possible with some eluents. For example with $5 \mathrm{~mL}$ of $0.5 \mathrm{M}$ $\mathrm{I}_{\mathrm{NO}}$, only nickel was recovered quantitatively. All lurther studies $10 \mathrm{~mL}$ of I M IINO; in acelone was used as eluent.

Sample and Eluent Flow Rates. Sample and eluent llow rates are important parameters to obtain quantitative reten- 
Table 1. Indluenees ol the certain sodium and ammonium salts as matrix on the recorerries of trate impurities $(\mathrm{N}=3, \mathrm{~V}=50 \mathrm{~mL})$

\begin{tabular}{|c|c|c|c|c|c|}
\hline \multirow{2}{*}{ Salt } & \multirow{2}{*}{$\begin{array}{c}\text { Concentration. } \\
\text { g: } 50 \mathrm{~mL}\end{array}$} & \multicolumn{4}{|c|}{ Recovery. ", } \\
\hline & & $\mathrm{ClI}$ & $\mathrm{Fe}$ & $\mathrm{Ni}$ & $\mathrm{Co}$ \\
\hline \multirow[t]{3}{*}{$\mathrm{NaCl}$} & ] & 97 & $1(n)$ & 100 & 95 \\
\hline & 5 & 97 & $1(n)$ & 100 & loter \\
\hline & ]10 & 100 & $1(n)$ & 100 & 95 \\
\hline \multirow[t]{3}{*}{$\mathrm{Nl} 1 . \mathrm{Cl}$} & l & 41 & 96 & 100 & $\operatorname{lok}$ \\
\hline & 5 & 71 & 95 & 100 & loter \\
\hline & ]1) & 44 & 95 & ]$(t) t$ & $\log (\mathrm{c}$ \\
\hline \multirow[t]{3}{*}{$\left(\mathrm{NI} \mathrm{I}_{1}\right)_{2} \mathrm{SO}$} & l & 95 & $1(6)$ & 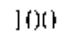 & $\log$ \\
\hline & 5 & 96 & 100 & 100 & $\operatorname{loth}$ \\
\hline & ]1) & 96 & $1(1)$ & 100 & 95 \\
\hline
\end{tabular}

tion and elution of antyte, respectively. The retentions for the analytes were vintually quantitative for sample flow rates up to $10 \mathrm{~mL} / \mathrm{min}$. Variation of the elution flow rate in the range of $1.0-6.0 \mathrm{~mL} / \mathrm{min}$ has no effect on the elution efficiency: In consequence. $5 \mathrm{~mL} / \mathrm{min}$ was selected as flow rate for loading and elution from the trap.

Effect of Salt Matrix. To investigate the effect of high concentrations of ammonium chloride, ammonium sulfate and sodium chloride salts on the recovery of analytes, the procedure were carried out with samples containing salts in the range of $1-10 \mathrm{~g}$ (Table $\mathrm{l}$ ). Quantitative recovery values for $\mathrm{Cu}$. Fe. Ni and Co up to $10 \mathrm{~g}$ of sodium chloride, for $\mathrm{Fe}$. $\mathrm{Ni}$ and $\mathrm{Co}$ up to $10 \mathrm{~g}$ of ammonium chloride. for $\mathrm{Cu}$. Fe, $\mathrm{Ni}$ and Co up to $10 \mathrm{~g}$ of ammonium sulfate were obtained. It was concluded that $\mathrm{Cu}(\mathrm{II}), \mathrm{Fe}(\mathrm{II}), \mathrm{Ni}(\mathrm{II})$ and $\mathrm{Co}(\mathrm{ll})$ occurring as impurities in ammonium and sodium salts can be determined with presented procedure.

Analytical Performance of the Method. The accuracy of the results was verified by analyzing the concentration after addition of known amounts of analytes into a $50 \mathrm{~mL}$ solution containing $5 \mathrm{~g} \mathrm{NaCl}$ and $\mathrm{NH} . \mathrm{Cl}$. Good agreement was obtained between the recovery of analyte for spiked and control samples using the experimental procedure for $\mathrm{Cu}$. $\mathrm{Fe}, \mathrm{Ni}$ and $\mathrm{Co}$ in $\mathrm{NaCl}$ and $\mathrm{Fe} . \mathrm{Ni}$ and $\mathrm{Co}$ in $\mathrm{NH}, \mathrm{Cl}_{\text {. Because }}$ of the recovery of $\mathrm{Cu}$ from $\mathrm{NH}_{4} \mathrm{Cl}$ were not quantitative, the determination of $\mathrm{Cu}$ in $\mathrm{NH}_{4} \mathrm{Cl}$ was not performed.

The reproducibility of the method was evaluated by passing $50 \mathrm{~mL}$ of solution containing $10 \mu \mathrm{g}$ of each analyte ion through Chromosorb-102 and repeating this procedure five times. The relative standard deviations were $\pm 2.7 \%$, $\pm 2.1 \% . \pm 1.6 \%, \pm 2.1 \%$ for copper, iron. nickel and cobalt. respectively. The detection limits of the analytes based on three times the standard deviations of the blank $(k=3$. $\mathrm{N}=20$ ) on a sample volume $50 \mathrm{~mL}$ for $\mathrm{Cu}$. Fe. $\mathrm{Ni}$ and $\mathrm{Co}$ were $17.0 \mu \mathrm{g} / \mathrm{L} .112 .9 \mu \mathrm{g} / \mathrm{L} .11 .0 \mu \mathrm{g} / \mathrm{L}, 6.0 \mu \mathrm{g} / \mathrm{L}$. respective1y. The detection limits of the analytes can be decreased by one order of magnitude by increasing the sample volume.

Application to Salt Samples. The method has been employed for the determination copper(II), iron (III), nickel(ll) and cobalt(II) ions in $\mathrm{NaCl}, \mathrm{NH} \cdot \mathrm{Cl}$ and $\left(\mathrm{NH}_{1}\right)_{2} \mathrm{SO}_{1}$ salts. The results, which are shown in Table 2 . have been calculated by assuming $100 \%$ recovery of the working elements. The relative standard deviations $(n=5)$ with related to the determinations in the salts for $\mathrm{Cu}$. Fe, $\mathrm{Ni}$ and Co were in the range of $4.0-9.7 \%$.

\section{Conclusion}

Because of $500 \mathrm{mg}$ of Cromosorb-102 resin can be used repeatedly for $300-400$ samples at least with $5 \mathrm{~mL} / \mathrm{min}$ of sample and eluent flow rates and the time required for the preconcentration and detemination was about 25 min. the proposed preconcentration system provides a fast and simple method for enrichment on Chromosorb-102. The deternination procedure was characterized by good reproducibility and accuracy.

\section{References}

1. Keil. O.: Duhmen. J.: Volmer. D. A. Fresen. J. Anat. Chem. 1999. 364.694

2. Turkoglu. O.: Soylak. M. Asion J. Chem. 2002. 14. 1698.

3. Mizuite. A. Fonichment Techniques for Inoryanic Trace Afallsis; Springer: Berlin, 1983: pp 1-18

4. Im, K. S. Pak, Y. M. J. Konean (hem. Soc. 1999, 43.644

5. Ivanowa. E.: Benkhedda. K.: Adams. F. J. Anat. Af Spect 1998. I.). 527 .

6. Torgox. V. G.: Demidoxa. M. G.: Saprykin. A. I.: Nikolaeva. I. V.: US. T. V.: Chebykin, F. P. J. Inal Chent 2002, 57, 303.

7. Yamini, Y: Chaloosi. M.: Foralimzadeh. H. likmolim teta 2002, 140. 195

8. Cyr. R. J.: Suri. R. P. S.: Helmig. E. D. Water Res. 2002. 36. 4725 .

9. Moldovan. Z.: Neagu. E. A. J. Surt. Chem. Soc. 2002. 67. 669 .

10. Bangasi, F. K.: Alam. S.: Iqbal. M. J. Chent Soc. Pakistan 2001. 23.215

11. Wasey, A.: Bansal, R. K.: Puri. B. K.: Rao. A. I. I. Talath 1984. 31.205 .

Table 2. The concentration of copper(Il), iron(IIl), nickel(II) and cobalt(II) in some sodium and ammonium salts

\begin{tabular}{|c|c|c|c|c|}
\hline \multirow{2}{*}{ Sample } & \multicolumn{4}{|c|}{ Concentration. $\mu \mathrm{g} \mathrm{g}^{a}$} \\
\hline & Cu & Fe & $\mathrm{Ni}$ & Co \\
\hline Refincd Table Salt & $0.11 \pm 0.01$ & $2.90 \pm 0.19$ & $0.39 \pm 0.02$ & B.L.D \\
\hline Unretined Table Salt & $0.09 \pm 0.01$ & $2.73 \pm 0.19$ & $0.45 \pm 0.02$ & $0.32 \pm 0.02$ \\
\hline $\mathrm{NaCl}$ (Analytical Reagent Grade) & $0.15 \pm 0.02$ & $1.56 \pm 0.16$ & $0.31 \pm 0.02$ & $0.28 \pm 0.02$ \\
\hline $\mathrm{NaCl}$ (Technical Grade) & $0.11 \pm 0.01$ & $1.53 \pm 0.14$ & $0.34 \pm 0.03$ & $0.19 \pm 0.02$ \\
\hline $\mathrm{NH}, \mathrm{Cl}$ (Analytical Reagent Grade) & N.D. & $3.24 \pm 0.28$ & $0.34 \pm 0.02$ & $0.25 \pm 0.02$ \\
\hline$\left(\mathrm{NH}_{1}\right)_{2} \mathrm{SO}_{1}$ (Analy tical Reagent Grade) & $0.07 \pm 0.01$ & $0.94 \pm 0.10$ & $0.16 \pm 0.01$ & $0.10 \pm 0.01$ \\
\hline
\end{tabular}

"P-0.95. t t.s viN, N- 5. BI.D: Below the Detection J.mit, ND: Not Detennined. 
12. Soylak. M.: Karatepe. A. U.: Elci. L.: Dogan. M. Tork. J. Chem. 2003. 27. 235

13. Cai. Y.: Jiang. G.: Liu. J. Tahanta 2002,57, 1173

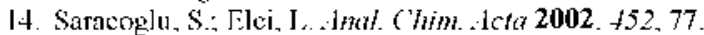

15. Cai, Y.: Jiang, G.: Jiu. J. Afrafyst 2001, 126. 1678.

16. Flej, I..: Arslan. 7.. Tyson. J. F. Spectrochim -1cta 2000, 55B. 1109 .

17. Cai. Y.: Jiang. G. B.: Liu. J. F.: Liang. X. Afom. Spectr. 2002. 23. 52.

18. Saracoglu, S.: Divrikli, U.: Soxlak. M.: Flci, I. J. Food Drug Anat 2002, 10, 188.

19. Cai, Y.: Jiang. G.: J.iu. J.: I Jc. B. Ahal Sci. 2002. 18. 705

20. Karatepe. A. U.: Soylak. M.: Elci. L. And Lafl. 2002. 35. 1561.
21. Saracoglu. S.: Soylak. M.: Elei. L.: Degan. M. Anat. Leff. 2002. 35. 1519.

22. Ferreira. S. L. C.: Lemos. V. A.: Moreira. B. C.: Conta. A. C. S.: Santelli. R. F. hal ( Wim. Acta 2000. 403,259

23. Ferreira. S. I. C.: Ferreira. I. R.: Dantas. A. F.: I cemos. V. A.:

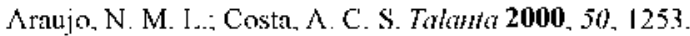

24. dos Dantos. H. C.: Kon. M. G. A.: Ferreira. S. L. C. Anal. Chim. Acta 2001. 426.79 .

25. Soylak. M.: Divritli. U.: Elci. L.: Dogan. M. Takenta 2002. 56. 565

26. Soylak. M: Saraooglu, S.: Fici. I.: Dogatn, M. Int. J. Emiron. Lindl $6 \%$ 2002. 82,225

27. Bendt. H.: Jackwerth. E. Spectruchim. fcta 1975. 30B. 169. 